\title{
Use of traditional medicines in the management of HIVIAIDS opportunistic infections in Tanzania: a case in the Bukoba rural district
}

\author{
Daniel P Kisangau*1,2, Herbert VM Lyaruu ${ }^{1}$, Ken M Hosea $^{3}$ and \\ Cosam C Joseph ${ }^{4}$
}

Address: ${ }^{1}$ Department of Botany, University of Dar es Salaam, PO Box 35060, Dar es Salaam, Tanzania, ${ }^{2}$ Department of Chemistry, University of Bielefeld, PO Box 100131 - 3350, Bielefeld, Germany, ${ }^{3}$ Department of Molecular Biology and Biotechnology, PO Box 35060, University of Dar es Salaam, Dar es Salaam, Tanzania and ${ }^{4}$ Department of Chemistry, University of Dar es Salaam, PO Box 35061, Dar es Salaam, Tanzania

Email: Daniel P Kisangau* - kisangau@yahoo.com; Herbert VM Lyaruu - lyaruu@amu.udsm.ac.tz; Ken M Hosea - hosea@amu.udsm.ac.tz; Cosam C Joseph - cosam@chem.udsm.ac.tz

* Corresponding author

Published: 10 July 2007

Journal of Ethnobiology and Ethnomedicine 2007, 3:29 doi:10.1 186/1746-4269-3-29

This article is available from: http://www.ethnobiomed.com/content/3/1/29

(C) 2007 Kisangau et al; licensee BioMed Central Ltd.

This is an Open Access article distributed under the terms of the Creative Commons Attribution License (http://creativecommons.org/licenses/by/2.0), which permits unrestricted use, distribution, and reproduction in any medium, provided the original work is properly cited.
Received: 9 March 2007

Accepted: 10 July 2007

\begin{abstract}
Background: Ethnobotanical surveys were carried out to document herbal remedies used in the management of HIV/AIDS opportunistic infections in Bukoba Rural district, Tanzania. The district is currently an epicenter of HIV/AIDS and although over $90 \%$ of the population in the district relies on traditional medicines to manage the disease, this knowledge is impressionistic and not well documented. The HIVIAIDS opportunistic conditions considered during the study were Tuberculosis (TB), Herpes zoster (Shingles), Herpes simplex (Genital herpes), Oral candidiasis and Cryptococcal meningitis. Other symptomatic but undefined conditions considered were skin rashes and chronic diarrhea.

Methods: An open-ended semi-structured questionnaire was used in collecting field information. Descriptive statistics were used to analyze the ethnobotanical data collected. Factor of informant consensus $\left(F_{i c}\right)$ was used to analyze the ethnobotanical importance of the plants.

Results: In the present study, 75 plant species belonging to 66 genera and $4 \mathrm{I}$ families were found to be used to treat one or more HIVIAIDS related infections in the district. The study revealed that TB and oral candidiasis were the most common manifestations of HIVIAIDS opportunistic infections affecting most of the population in the area. It unveils the first detailed account of ethnomedical documentation of plants focusing the management of HIV/AIDS related infections in the district.

Conclusion: It is concluded that the ethnopharmacological information reported forms a basis for further research to identify and isolate bioactive constituents that can be developed to drugs for the management of the HIV/AIDS opportunistic infections.
\end{abstract}

\section{Background}

According to WHO [1], traditional medicine continues to provide health coverage for over $80 \%$ of the world population, especially in the developing world. In many Afri- 
can countries including Tanzania, traditional healers play a crucial role of providing primary health care including taking care of people living with emerging diseases such as HIV/AIDS [2,3]. In 2006, almost two thirds (63\%) of all persons infected with HIV/AIDS in the world are living in sub-Saharan Africa [4]. HIV/AIDS pandemic is currently the most socio-economic challenge that faces Tanzania as it affects mostly the young and most economically productive population [5]. This translates to loss of skills, talents, expertise and man-hours. Majority of the people living with HIV/AIDS are susceptible to fungal and bacterial opportunistic infections that result from immunosuppression [Bii, 2001-unpublished abstract]. These infections have been reported from the early days of the HIV/AIDS pandemic [6] and are one of the leading causes of deaths in Tanzania and worldwide [7]. Treatment of such infections is therefore one of the most important factors for management of HIV/AIDS cases. However, poverty, high cost of life-enhancing drugs, resistance to conventional medicine and the serious side effects associated with antiretroviral drugs are the main draw backs to the use of conventional therapies.

More than $60 \%$ of the population in Tanzania depends on traditional medicines for the management of various diseases including HIV/AIDS [8]. Due to scarcity of drugs, many people living with HIV/AIDS opt for traditional health services for the control of the disease. Besides, the Lake Victoria basin which harbors the study area and the Great lakes region of East and Central Africa are now considered part of the global epicenter for HIV/AIDS, with $50 \%$ of bed occupancy in hospitals with AIDS patients in the mid-term to terminal stages of the disease [Aduma, 2001-unpublished abstract]. Furthermore, in this region more than any other in Tanzania, the HIV/AIDS pandemic has had the worst impact as it was the first to show a significant number of cases in the early 1980's, so that the disease has had the longest history in the region $[5,9]$. It is therefore reasonable to assume that the devastating impact of HIV/AIDS pandemic in the region and in Bukoba rural district in particular, coupled with the severe shortage of health personnel might have forced the inhabitants to develop coping mechanisms by adopting alternative sources of primary health care, one of which has been the use of herbal therapies.

Even though there are a good number of reports on traditional uses of plants to treat various diseases in the country, knowledge on herbal remedies used to manage HIV/ AIDS in particular is scanty, impressionistic and not well documented. Consequently, this paper presents the first detailed account of the status and use of traditional medicines in the management of HIV/AIDS opportunistic infections in Tanzania.

\section{Methods \\ The study area}

Bukoba rural district (Fig. 1) is among six administrative districts forming Kagera region in the Lake Victoria Basin in Tanzania. The district borders Uganda to the North, Lake Victoria to the East, Waters of Mara region to the South, Muleba district to the South East and Karagwe district to the West. It is composed of 168 villages in 41 wards and 6 divisions, and a total population of 395,130 [9]. The district is predominantly occupied by the Haya tribe who speak Kihaya language. Agriculture is the economic mainstay of the district and accounts for 50\% of the Region's Gross Domestic Product (GDP). The main crops are green bananas, coffee, beans, cotton and cassava. Other crops include sugarcane, sweet potatoes, vegetables, millet and sorghum [9]. The population-Doctor ratio stands at 95,000:1, the lowest of all the six districts in Kagera region [5,9], indicating a severe inadequacy of health personnel.

\section{Ethnobotanical surveys}

Ethnobotanical surveys were carried out in four out of the six divisions in the district. These were Kiamtwara, Misenye, Katerero and Rubale divisions. With a Prior Informed Consent (PIC), authentic and well known herbal practitioners were identified through Participatory Rural Appraisal (PRA) approach, with the assistance of local administrative officers. They were then interviewed using semi-structured open-ended questionnaires [10]. Interviews were conducted in the local Kihaya language except for a few cases where the respondents were erudite and could understand Kiswahili. Information regarding the local names of the plant species, parts used, preparation, administration and the disease condition treated was documented as shown in table 1 . The practitioners were also used as guides in field excursions to collect plant voucher specimens which were identified by Mr. Suleiman Haji and Mr. Frank Mbago of the University of Dar es Salaam, Department of Botany. The voucher specimens were later coded and deposited at Department of Botany herbarium, University of Dar es Salaam (Table 1). Factor of informant consensus $\left(\mathrm{F}_{\mathrm{ic}}\right)$ was used to analyze the ethnobotanical importance of the reported plant species according to Schlage et al. [11] and Owuor and Kisangau [12]. $\mathrm{F}_{\mathrm{ic}}$ gives the relationship between the number of usereports in each category $\left(n_{u r}\right)$ and number of taxa used $\left(n_{t}\right)$ :

$$
\mathrm{F}_{\mathrm{ic}}=\left(\mathrm{n}_{\mathrm{ur}}-\mathrm{n}_{\mathrm{t}} / \mathrm{n}_{\mathrm{ur}}-1\right)
$$

\section{Knowledge on HIVIAIDS opportunistic infections}

During the interviews, the symptoms of various HIV/AIDS opportunistic infections were described to the healers so as to enable them give the appropriate plant species they usually use to manage the infections [13,4,14-16] (Table 


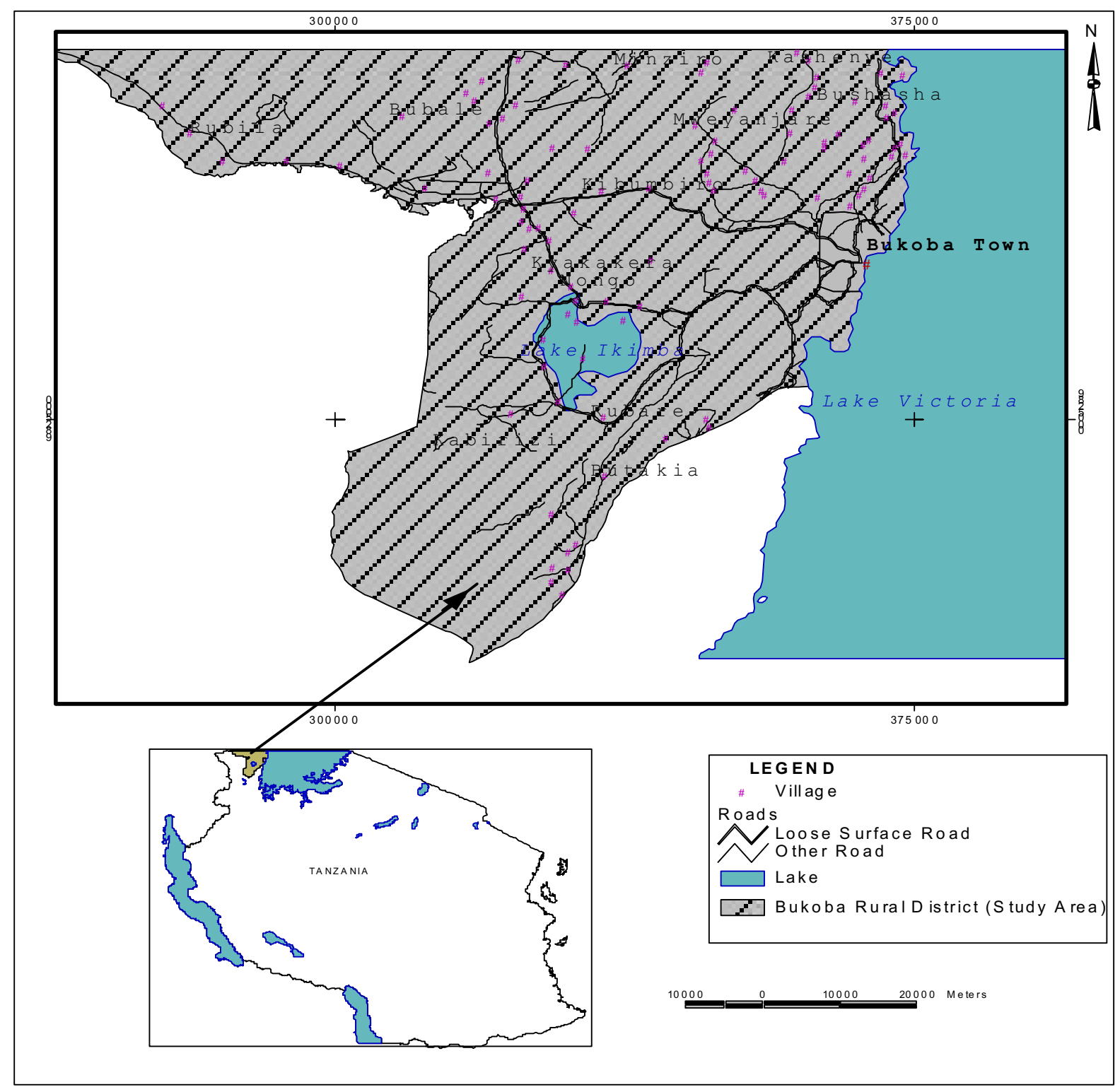

Figure I

A map showing the location of Bukoba rural district in Tanzania.

2). The Opportunistic infections considered in the present study were Tuberculosis (TB) locally called Ndwala enkuri, Oral candidiasis (Mbunya kanua), Cryptococcal meningitis (Mulalamo), Herpes zoster [Shingles] and Herpes simplex [Genital herpes] (Ebiere). The symptomatic conditions, skin rashes and chronic diarrhea are locally called Ubwere and Kuaruka respectively.

\section{Results}

A total of thirty herbal practitioners aged between 32 and 80 years of age were interviewed during the study. Twenty two out of the thirty respondents (73\%) were above 50 years of age. Twenty one of these were women and only nine were men, constituting a percentage of $70 \%$ and $30 \%$ respectively. Majority of the respondents were peasant 
Table I: Plant species used in treating various HIVIAIDS related conditions in Bukoba rural district

\begin{tabular}{|c|c|c|c|c|c|}
\hline Family & Plant name & Local name (Haya) & Part used & Condition treated & $\begin{array}{l}\text { Collection } \\
\text { code No. }\end{array}$ \\
\hline Acanthaceae & Thurnbergia alata Sims & Rwankura & Leaves/Roots & Oral candidiasis & DK0I3/06 \\
\hline Aloaceae & Aloe sp. & Enkaka & Leaves & Herpes zoster & DK046/06 \\
\hline \multirow[t]{6}{*}{ Anacardiaceae } & Mangifera indica $\mathrm{L}$. & Omunembe & Leaves & Tuberculosis (TB) & DK037/06 \\
\hline & Ozoroa insignis Del. & Omukerenge & Roots & $\begin{array}{l}\text { Skin rashes, Tuberculosis, Herpes simplex, } \\
\text { Herpes zoster, Cryptococcal menengitis, } \\
\text { Oral candidiasis }\end{array}$ & DK023/06 \\
\hline & Rhus natalensis Krauss & Omusheshe & Leaves/Roots & $\begin{array}{l}\text { Herpes zoster, Herpes simplex, } \\
\text { Cryptococcal meningitis, skin infections }\end{array}$ & DK044/06 \\
\hline & Rhus vulgaris Meikle & Omukanja & Leaves/Roots & Chronic diarrhea, skin rashes & DK036/06 \\
\hline & Pseudospondias microcarpa Engl. & Omuziru & Leaves/Bark & Tuberculosis, Oral candidiasis & DK005/06 \\
\hline & Lannea schimperi (A. Rich) Engl. & Ombumbo & Bark & $\begin{array}{l}\text { Tuberculosis, Skin rashes, Herpes zoster, } \\
\text { Herpes simplex, Chronic diarrhea }\end{array}$ & DK047/06 \\
\hline Annonaceae & Annona senegalensis Pers. & Omukonya & Root & $\begin{array}{l}\text { Herpes zoster, Cryptococcal meningitis, } \\
\text { Skin infections }\end{array}$ & DK034/06 \\
\hline Apocynaceae & Rauvolfia vomitoria Afz. & Omunyabusindi & Leaves/Bark/Roots & $\begin{array}{l}\text { Herpes zoster, Herpes simplex, Skin } \\
\text { rashes. }\end{array}$ & DK030/06 \\
\hline Araliaceae & Cussonia arborea Hochst. Ex A. rich & Kijagaajaga & Bark & Chronic diarrhoea & DK022/06 \\
\hline \multirow[t]{6}{*}{ Asteraceae } & Vernonia adoensis Walp. & Nyakibasi & Leaves & Tuberculosis & DK008/06 \\
\hline & Vernonia amygdalina Del. & Omumbilizi & Leaves & $\begin{array}{l}\text { Skin rashes, Chronic diarhhoea, Herpes } \\
\text { zoster, Herpes simplex, Cryptococcal } \\
\text { meningitis. }\end{array}$ & DK016/06 \\
\hline & Senecio syringifolius O. Hoffm. & Ekishenda & Roots & Herpes simplex & DK03I/06 \\
\hline & Ageratum conyzoides L. & Kyabakiriao & Leaves & Cryptococcal meningitis, Herpes zoster. & DK025/06 \\
\hline & Bidens pilosa $\mathrm{L}$. & Mbukurura & Leaves & Oral candidiasis. & DK054/06 \\
\hline & Conyza floribunda H.B.K. & Lukobe & Leaves & Skin rashes & DK027/06 \\
\hline Bignonaceae & Kigelia africana (Lam.) Benth. & Omujunguti & Bark/Fruit & Herpes simplex & DK032/06 \\
\hline \multirow[t]{3}{*}{ Caesalpiniaeae } & Cassia abbreviate Oliv. & - & Leaves & Skin rashes & DK045/06 \\
\hline & Senna occidentalis (L.) Link & Mwita njoka & Roots & Chronic diarrhea & DK02I/06 \\
\hline & Cassia mimosoides L. & Akashanganziru & Leaves/Roots & Tuberculosis & DK024/06 \\
\hline \multirow[t]{3}{*}{ Capparaceae } & Capparis erythrocarpos Isert & Oluvuranganga & Roots & $\begin{array}{l}\text { Skin rashes, Tuberculosis, Cryptococcal } \\
\text { meningitis, Oral candidiasis, Herpes } \\
\text { zoster, Herpes simplex, chronic diarrhoea }\end{array}$ & DK028/06 \\
\hline & Gynadropsis gynandra (L.) Briq. & Eiopyo & Leaves & Oral candidiasis, Oral sores & DK033/06 \\
\hline & Capparis tomentosa Lam. & Omukolokomba/Rukwatango & Roots & $\begin{array}{l}\text { Tuberculosis, Oral candidiasis, Herpes } \\
\text { zoster, Herpes simplex }\end{array}$ & DK020/06 \\
\hline Caricaceae & Carica papaya L. (male) & - & Leaves/Roots & Oral candidiasis & DK035/06 \\
\hline Celastraceae & Maytenus senegalensis (Lam.) Exell & Omunyambuliko & Bark/Root & $\begin{array}{l}\text { Herpes simplex, Herpes zoster, Oral } \\
\text { candidiasis, Skin rashes, Tuberculosis }\end{array}$ & DK0I8/06 \\
\hline \multirow[t]{2}{*}{ Chenopodiaceae } & $\begin{array}{l}\text { Chenopodium opulifolium Koch. \& } \\
\text { Ziz. }\end{array}$ & Mwitango & Leaves & Herpes simplex & DK0I5/06 \\
\hline & Chenopodium Ambrosioides L. & Akaita malogo & Leaves & Herpes simplex, cryptococcal meningitis & DK056/06 \\
\hline Chrysobalanaceae & Parinari curatellifolia Benth. & Omunazi & Bark/Root & $\begin{array}{l}\text { Skin rashes, Tuberculosis, Chronic } \\
\text { diarrhea, Herpes zoster, Herpes simplex. }\end{array}$ & DK039/06 \\
\hline \multirow[t]{3}{*}{ Clusiaceae } & Garcinia buchananii Bak. & Omusharazi & Bark/Root & $\begin{array}{l}\text { Tuberculosis, Chronic diarrhoea, } \\
\text { Cryptococcal Meningitis, Herpes zoster, } \\
\text { Herpes simplex, Skin rashes }\end{array}$ & DK063/06 \\
\hline & Psorospermum febrifugum Spach. & Ekiana & Bark/Root & $\begin{array}{l}\text { Herpes zoster, Herpes simplex, } \\
\text { Cryptococcal meningitis, Skin infections. }\end{array}$ & DK003/06 \\
\hline & $\begin{array}{l}\text { Harungana madagascariensis Lam. Ex } \\
\text { Poir }\end{array}$ & Omujumbo & Leaves/Bark & Chronic diarrhea & DK006/06 \\
\hline \multirow[t]{2}{*}{ Combretaceae } & Combretum collinum Sound. & Omukoyoyo & Leaves/Bark/Roots & Chronic diarrhea, Tuberculosis & DK04I/06 \\
\hline & Terminalia mollis Laws & Muhongora & Bark & Cryptococcal meningitis, Tuberculosis & DK058/06 \\
\hline Convolvulaceae & Ipomoea sinensis (Desr.) Choisy & Omusinda nyungu & Leaves & Oral candidiasis, Tuberculosis & DK055/06 \\
\hline Cucurbitaceae & Zehneria scabra (L.f.) Sond. & Akabindizi & Whole plant & $\begin{array}{l}\text { Cryptococcal meningitis, Oral candidiasis, } \\
\text { Skin rashes, Herpes simplex. }\end{array}$ & DK0I7/06 \\
\hline
\end{tabular}


Table I: Plant species used in treating various HIVIAIDS related conditions in Bukoba rural district (Continued)

\begin{tabular}{|c|c|c|c|c|c|}
\hline Dennstaedtiaceae & Pteridium aquilinum (L.) Kuhn. & Olulele & Leaves & Oral candidiasis, Tuberculosis & DK029/06 \\
\hline Dracaenaceae & Dracaena steudneri Engl. & Omugorogoro & Bark & $\begin{array}{l}\text { Cryptococcal meningitis, Tuberculosis, } \\
\text { Oral candidiasis }\end{array}$ & DK0I4/06 \\
\hline \multirow[t]{5}{*}{ Euphorbiaceae } & Sapium ellipticum (Krauss) Pax & Omushasha & Bark & $\begin{array}{l}\text { Tuberculosis, Herpes zoster, } \\
\text { Cryptococcal meningitis }\end{array}$ & DK019/06 \\
\hline & Ricinus communis L. & Omujuna & Roots & Chronic cough & DK048/06 \\
\hline & Jatropha curcas L. & Ekiyo & Leaves & Skin rashes, Oral candidiasis & DKOII/06 \\
\hline & Antidesma venosum Tul. & Mbatabata & Roots & $\begin{array}{l}\text { Tuberculosis, Chronic diarrhoea, Oral } \\
\text { candidiasis }\end{array}$ & DK049/06 \\
\hline & Phyllanthus reticulatus poir. & Kaumura & Leaves & Herpes simplex & DK076/06 \\
\hline \multirow[t]{3}{*}{ Lamiaceae } & Plectranthus barbatus Andr. & Kasindano/Kishwija & Leaves & $\begin{array}{l}\text { Oral candidiasis, Herpes zoster, Herpes } \\
\text { simplex, Skin rashes }\end{array}$ & DKOI0/06 \\
\hline & Plectranthus comosus Sims & Mukono wa nkanda & Leaves & $\begin{array}{l}\text { Herpes zoster, Herpes simplex, Skin } \\
\text { rashes, Oral candidiasis, Tuberculosis }\end{array}$ & DK07I/06 \\
\hline & Ocimum gratissimum L. & Kashwagara & Leaves & Chronic diarrhea, Herpes simplex & DK065/06 \\
\hline Malvaceae & Hibiscus fuscus Garcke & Olushuya & Leaves & Chronic diarrhoea & DK053/06 \\
\hline \multirow[t]{3}{*}{ Mimosaceae } & Entada abyssinica A. rich. & Mwiganjura & Leaves/Bark & $\begin{array}{l}\text { Skin rashes, Tubercuilosis, Oral } \\
\text { candidiasis, Herpes zoster, Herpes } \\
\text { simplex. }\end{array}$ & DK026/06 \\
\hline & Entada leptostachya Steud ex A. rich. & Ekitakuli & Roots & $\begin{array}{l}\text { Skin rashes, Tuberculosis, Herpes simplex, } \\
\text { Herpes zoster }\end{array}$ & DK043/06 \\
\hline & Acacia hockii De Willd. & Mugando & Bark & Herpes zoster & DK038/06 \\
\hline Myricaceae & Myrica salicifolia A. Rich. & Omukikimbo & Bark/Root & $\begin{array}{l}\text { Tuberculosis, Chronic diarrhea, } \\
\text { Cryptococcal meningitis, Herpes simplex }\end{array}$ & DK057/06 \\
\hline \multirow[t]{3}{*}{ Myrtaceae } & Psidium guajava $\mathrm{L}$. & Omupera & Leaves & Tuberculosis, Chronic diarrhea & DK042/06 \\
\hline & Syzygium guineense (Willd) DC & Omuchwezi & Bark & Chronic diarrhea & DK059/06 \\
\hline & Syzygium cordatum Krauss & Omugege & Leaves/Bark & $\begin{array}{l}\text { Herpes zoster, Herpes simplex, Skin } \\
\text { rashes }\end{array}$ & DK070/06 \\
\hline Olacaceae & $\begin{array}{l}\text { Ximenia americana var. caffra (Sond.) } \\
\text { Engl. }\end{array}$ & Omusheka & Roots & Skin rashes & DK074/06 \\
\hline Papaveraceae & Argemone mexicana $\mathrm{L}$. & Akatojo & Leaves/Seeds & Cryptococcal meningitis & DK062/06 \\
\hline \multirow[t]{4}{*}{ Papillionaceae } & Erythrina abyssinica DC. & Omurinzi & Bark/Root & Tubeculosis & DK040/06 \\
\hline & Eriosema psoraleoides (Lam.) G. Don. & Omukakara & Leaves & Chronic diarrhea & DK077/06 \\
\hline & Abrus precatorius $\mathrm{L}$. & Kaligaligo & Leaves & Oral candidiasis & DK052/06 \\
\hline & Cajanus cajan (L.) Millsp. & Mtandaikwa & Stem string & Oral candidiasis & DK066/06 \\
\hline Passifloraceae & Adenia gummifera (Harv) Harms. & Nyarimari & Stem/Root & Oral candidiasis & DK073/06 \\
\hline Phytolacaceae & Phytolacca dodecandra L'Herit & Muhoko & Leaves & Herpes zoster, Skin rashes. & DK079/06 \\
\hline Polygalaceae & Securidaca longipedunculata Fres. & Omweiya & Leaves/Bark/Root & Cryptococcal meningitis, Oral candidiasis & DK069/06 \\
\hline Polygonaceae & $\begin{array}{l}\text { Rumex usambarensis (Dammer) } \\
\text { Dammer }\end{array}$ & Akarurinzi & Leaves/Roots & $\begin{array}{l}\text { Chronic diarrhea, Oral candidiasis, Skin } \\
\text { infections }\end{array}$ & DK060/06 \\
\hline Ranunculaceae & Clematis hirsute Guill. \& Perr. & Omnkamba & Leaves & $\begin{array}{l}\text { Tuberculosis, Cryptococcal meningitis, } \\
\text { Herpes zoster }\end{array}$ & DK05I/06 \\
\hline \multirow[t]{3}{*}{ Rubiaceae } & Canthium zanzibarica Klotzsch. & Omushangati & Bark/Root & Cryptococcal meningitis & DK080/06 \\
\hline & Tarenna graveolens (S.Moore) Breun. & Omushangati & Bark/Roots & Cryptococcal meningitis & DK067/06 \\
\hline & Vagueria infausta Hochst. & Mubungo & Leaves & Oral candidiasis & DK06I/06 \\
\hline Rutaceae & Citrus limon (L.) Burm.f. & - & Root & Tuberculosis & DK075/06 \\
\hline Sapindaceae & Allophyllus africanus Beauv. & Katatera Mnyanya & Leaves & Chronic diarrhea & DK050/06 \\
\hline Tiliaceae & Grewia bicolor Juss & Omukoma & Leaves/Bark/Roots & Chronic diarrhea & DK064/06 \\
\hline Ulmaceae & Trema orientalis (L.) Blume & Muuwe & Leaves & Oral candidiasis & DK078/06 \\
\hline Verbenaceae & Vitex fischeri Gurke & Omuunda & Bark & $\begin{array}{l}\text { Herpes zoster, Tuberculosis, Herpes } \\
\text { simplex, Skin rashes }\end{array}$ & DK068/06 \\
\hline Vitaceae & $\begin{array}{l}\text { Rhoicissus tridentate (L.f.) Wild \& } \\
\text { Drum. }\end{array}$ & Ekimara & Leaves & Herpes zoster & DK072/06 \\
\hline
\end{tabular}


Table 2: Symptoms of HIVIAIDS opportunistic infections described to the traditional healers during the interviews

\begin{tabular}{ll}
\hline Disease condition & Symptoms \\
\hline $\begin{array}{l}\text { Tuberculosis } \\
\text { Oral candidiasis }\end{array}$ & $\begin{array}{l}\text { Persistent or chronic cough, Mucopurulent sputum, recurring dull, aching pain or tightness in the chest and Dyspnea } \\
\text { Oral thrush, Oral mucosal lesions, mouth ulcers and difficulty in swallowing }\end{array}$ \\
Cryptoccocal meningitis & $\begin{array}{l}\text { Fever, frequent headache, mental confusion, seizures, malaise and fatigue } \\
\text { Herpes zoster }\end{array}$ \\
Lecalized burning sensation, reddening of the skin followed by the appearance of grouped, dense blisters (Vesicles) and \\
sores on the skin
\end{tabular}

farmers and non- educated. It was found that most informants could unambiguously characterize symptoms of the targeted HIV/AIDS opportunistic infections without much problem. During the study, 75 plant species in 66 genera and 41 families were known to be used to treat one or more of the reported HIV/AIDS related infections in the district. The families Anacardiaceae, Asteraceae, Capparaceae, Clusiaceae, Euphorbiaceae, Papillionaceae, Rubiaceae, Myrtaceae, Mimosaceae and Lamiaceae constituted $52 \%$ of all the reported plant species, with each family having three or more species associated with the treatment of the opportunistic infections documented. The highest number of plant species used to treat the various conditions was recorded for TB which had 27 of the 75 documented species. It was followed by oral candidiasis with 25, Herpes zoster (23), H. simplex (23), skin rashes (23) chronic diarrhea (21) and cryptococcal meningitis (17) (Fig. 2). Thirty five of the 75 plant species were used to manage only one of the seven conditions reported, 39 were used to manage two up to six of the conditions, while one plant species only, Capparis erythrocar-

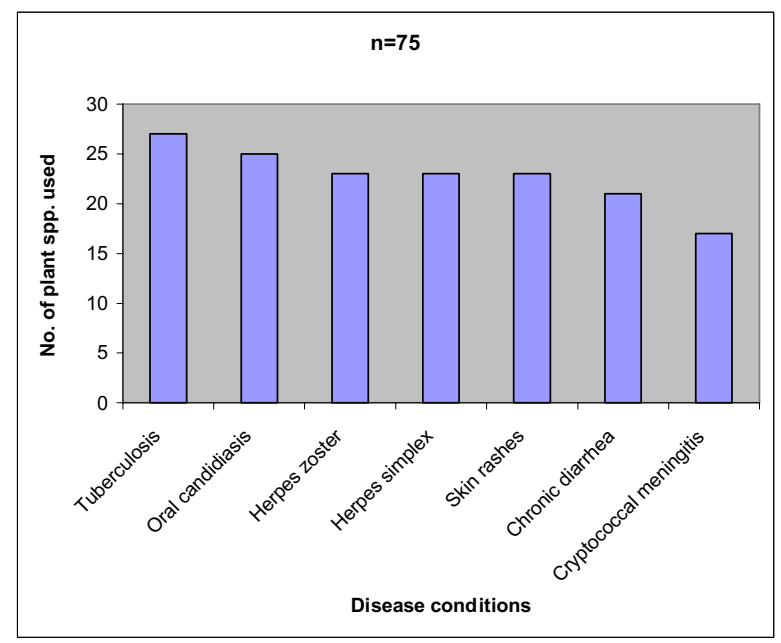

\section{Figure 2}

Disease conditions versus the number of plant species used to treat them. pos was used to treat all the seven reported disease conditions.

There were a total of 249 independent informant reports on plant usage against the various reported conditions. The total number and the percentage informant reports for each condition are shown in table 3.

The study revealed that leaves were the most popular parts used in preparing herbal remedies and comprised $42 \%$ of all the reports on use of plant parts. This was followed by roots $(29 \%)$, stem or bark $(26 \%)$ and other parts of plants like fruits or seeds (3\%) (Fig. 3). Most of these plant parts were harvested unsustainably without putting any consideration for future resource availability. For example, there was evidence of total ring barking of trees, total uprooting or cutting of the whole plant.

Different methods were employed in preparing and dispensing herbal remedies as shown in table 4 and Fig. 4 .

The most common method of drug administration was by oral application of decoctions or infusions, especially for conditions like TB, Herpes zoster, H. simplex and Cryptococcal menengitis. Powdered medicines were mixed with jelly and applied as ointments for skin eruptions. Alternatively, decoctions or infusions were bathed with for the skin infections. Licking was especially employed for oral infections like oral candidiasis.

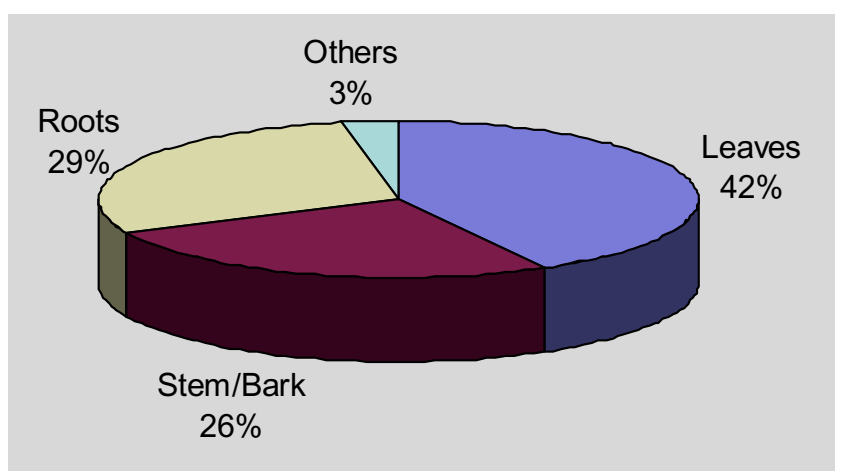

Figure 3

Percentage use of plant parts. 
Table 3: Percentage informant reports on plant usage against the various conditions

\begin{tabular}{lll}
\hline Condition & $\begin{array}{l}\text { Number of } \\
\text { reports }\end{array}$ & Percentage \\
\hline Herpes zoster & 50 & $20 \%$ \\
Skin rashes & 42 & $17 \%$ \\
Tuberculosis & 38 & $15 \%$ \\
Herpes simplex & 34 & $14 \%$ \\
Oral candidiasis & 33 & $13 \%$ \\
Cryptococcal & 30 & $12 \%$ \\
meningitis & & \\
Chronic diarrhoea & 22 & $9 \%$ \\
Total & 249 & $100 \%$ \\
\hline
\end{tabular}

The use of the Factor of informant consensus $\left(\mathrm{F}_{\mathrm{ic}}\right)$ arrived at the value of 0.70 . A high $\mathrm{F}_{\mathrm{ic}}$ value (close to 1 ) indicates that the informants use relatively few taxa to manage specific disease conditions as well as consistency in the use of plant species, while a low value indicates that the informants disagree on the taxa to be used in the treatment within a category of illness[11,12].

\section{Discussion}

The fact that $73 \%$ of the respondents were aged above 50 years implies that the legacy of the use of traditional medicines to manage HIV/AIDS related infections is in danger of being irrevocably lost if quick efforts are not exerted to document this invaluable knowledge. It is important to note that the sum of plant species used to treat each of the disease conditions as shown in Fig. 2 surpasses the total 75 plant species recorded during the study. This is because many of the plant species reported are used to treat more than one diseases condition.

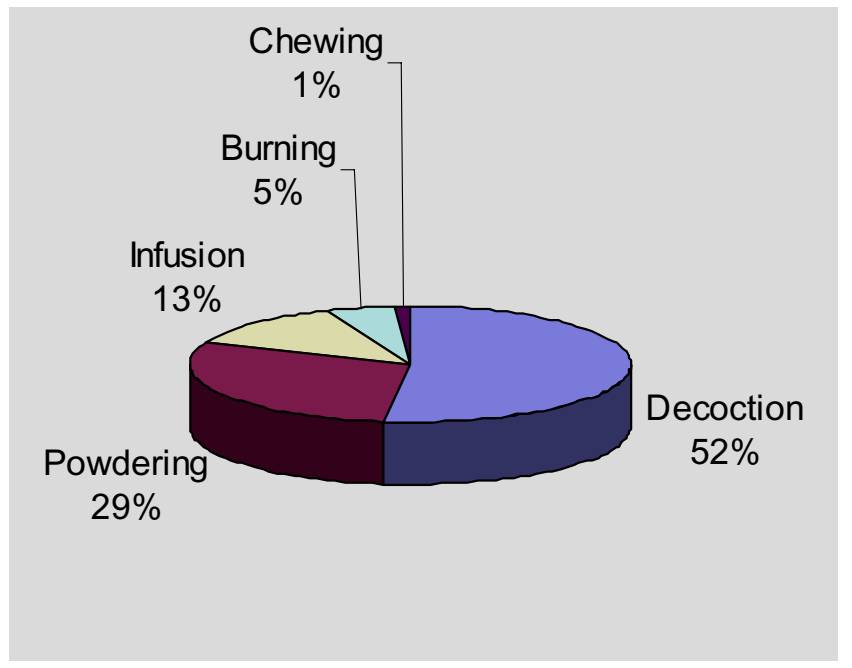

Figure 4

Percentage forms of herbal preparations.
Table 4: Percentage forms of preparing herbal remedies

\begin{tabular}{ll}
\hline Method of preparation & Percentage \\
\hline Boiling (Decoctions) & $52 \%$ \\
Drying in sun and pulverization & $29 \%$ \\
Soaking in cold water (Infusion) & $13 \%$ \\
Burning & $5 \%$ \\
Chewing & $1 \%$ \\
\hline
\end{tabular}

It is worthy noting that the highest number of the reported herbal remedies was associated with treatment of TB but the highest consensus number of independent reports on the plant remedies against the disease conditions was observed for Herpes zoster. Thus, the degree of informant conformity on a particular plant species in treating a particular disease condition is more important in reflecting the bioactivity potential of the plants than the numerical status of the plants used to treat the condition.

On one hand, the relatively high $\mathrm{F}_{\mathrm{ic}}$ value (0.70) derived suggests that there was a great agreement amongst the respondents on the use of different plant species to manage the reported disease conditions. On the other hand, it reflects the likelihood of presence of bioactive molecules to curtail the various HIV/AIDS opportunistic infections reported. A similar observation was made by Schlage et al. [11] who used $\mathrm{F}_{\mathrm{ic}}$ to evaluate the ethnobotanical importance of the medicinal plants of Washambaa in Tanzania. $\mathrm{F}_{\mathrm{ic}}$ is also a crucial tool in establishing a comparative estimation of the level of informant consensus on the use of herbal remedies between culturally different communities [12].

The supremacy of the families Anacardiaceae, Asteraceae, Capparaceae, Clusiaceae, Euphorbiaceae, Lamiaceae, Mimosaceae, Myrtaceae, Papillionaceae and Rubiaceae in the management of the reported conditions could be associated with the presence of certain bioactive secondary metabolites. For example, the families Myrtaceae and Lamiaceae are rich in terpenoids which are biologically responsible for the general improvement and maintenance of body health [17], with a prospective role of boosting the body immunity and consequential potential of managing the reported opportunistic infections. The family Anacardiaceae is rich in tannins, flavonoids and triterpenes which are responsible for prevention of diarrhea, dermal ulcers, general skin eruptions and abdominal pains [18-22]. This may support the pertinent traditional uses of Ozoroa insignis, Rhus natalensis, R. vulgaris and Lannea schimperi in their respective treatment of skin rashes, Herpes simplex, H. zoster and chronic diarrhea as reported in Table 1. 
The ethnomedical uses of some plants described here are consistent with data reported previously. For instance, the traditional use of Harungana madagascariensis among the Igbos of southeastern Nigeria for the treatment of diarrhea has been reported by Okoli et al. [21]. The use of Psorospermum febrifugum by the Kamba of Kenya and the Washambaa of Tanzania in the treatment of skin infections $[19,23]$ also concurs with the findings of the present study. Similarly, the use of Garcinia huillensis and Securidaca longipedunculata to treat Cryptococcal meningitis is consistent with data reported by Mathias [24]. Such a similarity in the cross-cultural usage of plant remedies is a strong indication of the bioactivity potential of the reported plants.

\section{Conclusion}

The information provided forms a strong basis for conservation of the reported remedies, considering that a greater percentage of the plant parts used were roots and stem/ bark. Continuous unsustainable harvesting of these plant parts may eventually lead to disappearance of these invaluable resources if early conservation measures are not taken. In future, there would be a need to engage in value adding and standardization of the herbal preparations by developing the necessary dosages and packaging of the herbal formulations. The ethnopharmacological information reported forms a crucial lead for further research to identify and isolate bioactive constituents that can be developed to drugs for the management of the HIV/AIDS opportunistic

infections.

\section{Competing interests}

The author(s) declare that they have no competing interests.

\section{Authors' contributions}

DPK was involved in the conception, acquisition and analysis of data, drafting and final revision of the manuscript. HVML designed the research layout, was involved in data analysis and interpretation, and critically revised the manuscript for important intellectual content. KMH and CCJ were involved in the conception, designing of the research and critical revision of the manuscript for important intellectual content. All authors read and approved the final manuscript.

\section{Acknowledgements}

DAAD/NAPRECA and The Inter-University Council of East Africa Research initiative-VicRes are acknowledged for financial support. We thank the respondents and the general community in Bukoba Rural district for their cooperation during the field data collection period. Messrs F.M. Mbago and S. Haji of the Herbarium, Botany department are thanked for identifying the plants.

\section{References}

I. WHO: Traditional Medicine; Growing Needs and Potential. WHO Policy Perspectives on Medicines. World HealthOrganization, Geneva 2002:I-6.
2. Scheinman $D$ : The ancient and modern worlds unite to fight HIVIAIDS in Tanga, Tanzania. Merck; Science in Africa online magazine. 2002 [http://www.scienceinafrica.co.za/2002/sep tember/tanga.htm].

3. Kala CP, Farooquee NA, Dhar U: Prioritization of medicinal plants on the basis of available knowledge, existing practices and use value status in Uttaranchal, India. J Biodiver and Conserv 2004, 13:453-469.

4. UNAIDS/WHO: AIDS epidemic update: December 2006. $: 1-90$.

5. Tanzania Commission for AIDS (TACAIDS), National Bureau of Statistics (NBS) and ORC Macro: Tanzania HIVIAIDS indicator survey 2003-04. Calverton, Maryland, USA 2005.

6. Hodgson $T$, Rachanis $C$ : Oral fungal and bacterial infections in HIV-infected individuals: an overview in Africa. J Oral diseases 2002, 8:80-87.

7. National Institute for Medical Research (NIMR). TB/HIV/Malaria: Challenges to the health systems in Africa in the era of globalization. Proceedings of the 19th Annual joint scientific conference, Arusha International Conference Centre, Arusha, Tanzania . March I5-17 2004

8. Mhame PP, Nyigo VA, Mbogo GP, Wiketye VE, Kimaro G, Mdemu A, Ogondiek JW, Imeda CP, Malecela-Lazaro MN, Kitua AY: The management of HIVIAIDS-related conditions using a traditional herbal preparation-muhanse $m 4^{\circledR}$ in Tanzania: A case study in Dar- es-Salaam, Tanzania. National institute for medical research, Dar-es-Salaam, Tanzania 2004.

9. The United Republic of Tanzania (TUROT): Kagera Region Socioeconomic profile $\left(\mathbf{2}^{\text {nd }}\right)$. National Bureau of Statistics (NBS) and Kagera Regional Commissioner's office, Tanzania 2003.

10. Martin GJ: Ethnobotany: A people and plants conservation manual. Chapman \& Hall; London 1995.

II. Schlage C, Mabula C, Mahunnah RLA, Heinrich M: Medicinal plants of the Washambaa (Tanzania): documentation andethnopharmacalogical evaluation. Plant biol 2000, 2:83-92.

12. Owuor BO, Kisangau DP: Kenyan medicinal plants used as antivenin: a comparison of plant usage. I Ethnobiol Ethnomedicine 2006, 2:7.

13. American Thoracic Society (ATS): Diagnostic Standards and Classification of Tuberculosis. American Review of Respiratory Disease 1990, I42(3):725-735.

14. Centre for Disease Control (CDC): Fact Sheet: Cryptococcal meningitis. The National Institute of Allergy and Infectious Disease (NIAID), USA 1994.

15. Moon JE: Herpes zoster. E-medicine online information. [http://www.emedicine.com/med/topic/007.htm].

16. Simmers L: Introduction to Health Science technology. Thomsons Delmer learning Itd. Australia 2003:22I.

17. Wagner KH, Emadfa I: Biological relevance of terpenoids: Overview focusing on mono-, di and tetraterpenes. Annals of Nutrition and metabolism 2003, 47:95-106.

18. Rwagabo PC: Umuhengerin, a new antimicrobially active flavonoid from Lantana trifolia. Journal of natural products 1988, $5 I(5): 966-968$.

19. Kokwaro JO: Medicinal plants of East Africa. 2nd edition. Kenya Literature Bureau; Nairobi, Kenya; 1993.

20. Mona H: Health benefits of Morinda citrifolia. Consumer health 1997, 20:12.

21. Okoli AS, Okeke MI, Iroegbu CU, Ebo PU: Antibacterial activity of Harungana madagascariensis leaf extracts. Phytother Res 2002, I6(2): 174-9.

22. Repetto MG, Llesuy SF: Antioxidant properties of natural compounds used in popular medicine for gastric ulcers. Brazilian journal of medical and biological research 2002, 35(5):523-534.

23. Moshi J, Mbwambo ZH, Nondo RSO, Masimba PJ, Kamuhabwa A, Kapingu MC, Thomas P, Richard M: Evaluation of ethnomedical claims and Brine shrimp toxicity of some plants used in Tanzania as Traditional medicines. African Journal of Traditional, Complementary and Alternative Medicines 2006, 3(3):48-58.

24. Mathias ME: Some medicinal plants of the Hehe (Southern highlands province, Tanzania). Taxon 1982, 3 I (3):488-494. 